УДК 616.367-007.253-007.272-0

DOI 10.11603/2414-4533.2019.2.10411

(СВ. І. РУСИН, К. Є. РУМЯНЦЕВ, Ф. М. ПАВУК

ДВНЗ "Ужгородський національний університет"

\title{
Лікування синдрому Міріззі
}

\begin{abstract}
Мета роботи: визначення способу лікування спонтанних внутрішніх біліарних нориць (СВБН) при синдромі Міріззі (СМ). Матеріали та методи. Проведено ретроспективний аналіз результатів лікування 8200 пацієнтів із жовчнокам’яною хворобою в Закарпатській обласній клінічній лікарні ім. Андрія Новака (ЗОКЛ) з 1997 до 2018 р. Із загальної кількості у 199 пацієнтів спостерігали СВБН. Частота, з якою траплялися СВБН, склала 2,4 \%.

Результати досліджень та їх обговорення. Пацієнтам із СМ 1 типу виконували холецистектомію із зашиванням широкої і короткої міхурової протоки. У 30 хворих із СМ 2 типу виконали холецистектомію від дна з висіканням норицевого ходу і зашиванням дефекту в загальній жовчній протоці (ЗЖП) на Т-подібній трубці. У 14 хворих із СМ 3 типу варіантом вибору була холецистектомія з пластикою ЗЖП залишками стінки жовчного міхура (ЖМ) і зовнішнім дренуванням Т-подібною трубкою. У 9 хворих із синдромом Міріззі 4 типу виконали холецистектомію “від дна” із повним пересіканням ЗЖП. Дев’ятнадцяти хворим із холедохо-дуоденальними норицями 1 типу виконано ендоскопічну папілофістулотомію з метою надійного дренування ЗЖП, евакуації конкрементів 3 неї і ліквідації внутрішнього отвору нориці. Метою операції при спонтанних внутрішніх біліарних норицях є видалення жовчного міхура, забезпечення відтоку жовчі у просвіт травної трубки і пасажу хімусу по ній. При наявності нориці в порожнистому органі виконується ії висікання з ушиванням отвору, окремих випадках резекційні способи ліквідації нориць.
\end{abstract}

Ключові слова: синдром Міріззі; механічна жовтяниця; холедохолітіаз; спонтанні внутрішні біліарні нориці.

Постановка проблеми і аналіз останніх досліджень та публікацій. Синдром Міріззі (СМ), або синдром зовнішнього стиснення - рідкісне ускладнення холециститу і хронічного холелітіазу, вторинного відносно обструкції перешийку жовчного міхура або міхурової протоки, зумовлене впливом одного або декількох конкрементів в цих анатомічних структурах, що призводить до стиснення прилеглої жовчної протоки, що призводить до часткової або повної обструкції загального печінкового протоку, зумовлюючи порушення функції печінки [1-4]. У 1982 р. Макшері та ін. класифіковали синдром Міріззі двома типами на підставі результатів ендоскопічної ретроградної холангіографії. Тип 1 включав часткову або повну зовнішню обструкцію загального печінкового протоку каменем, що вклинився в міхуровій протоці або в кишені Гартмана, і спричиняв запалення в зоні трикутника Кало. Тип 2 асоціювався 3 формування зв'язку між міхуровою протокою і загальною печінковою протокою, що супроводжується утворенням холецистохоледохеальної фістули, спричиненої ерозією стінок каменем в загальній протоці [6-9,10]. У1989 р. Csendes та ін. класифікували синдром Міріззі за чотирма типами відносно холецистохоледохеальних фістул і ступеня деструкції стінок. У 2007 p. Csendes додає додатковий тип до класифікації, який був підтверджений Белтраном [1-9,10].

Мета роботи: визначення способу лікування спонтанних внутрішніх біліарних нориць при синдромі Міріззі.
Матеріали і методи. Проведено ретроспективний аналіз результатів лікування 8200 пацієнтів із жовчнокам'яною хворобою в Закарпатській обласній клінічній лікарні ім. Андрія Новака (ЗОКЛ) з 1997 до 2018 р. Із загальної кількості у 199 пацієнтів спостерігали СВБН. Частота, з якою траплялися СВБН, склала 2,4 \%. Чоловіків було 63 (31,7 \%), жінок - 135 (68,3 \%). Вік пацієнтів коливався в межах від 37 до 80 років (в середньому 66,4 року). Розподіл пацієнтів проводили згідно 3 класифікацією А. Csendes та M. Beltran (рис. 1).

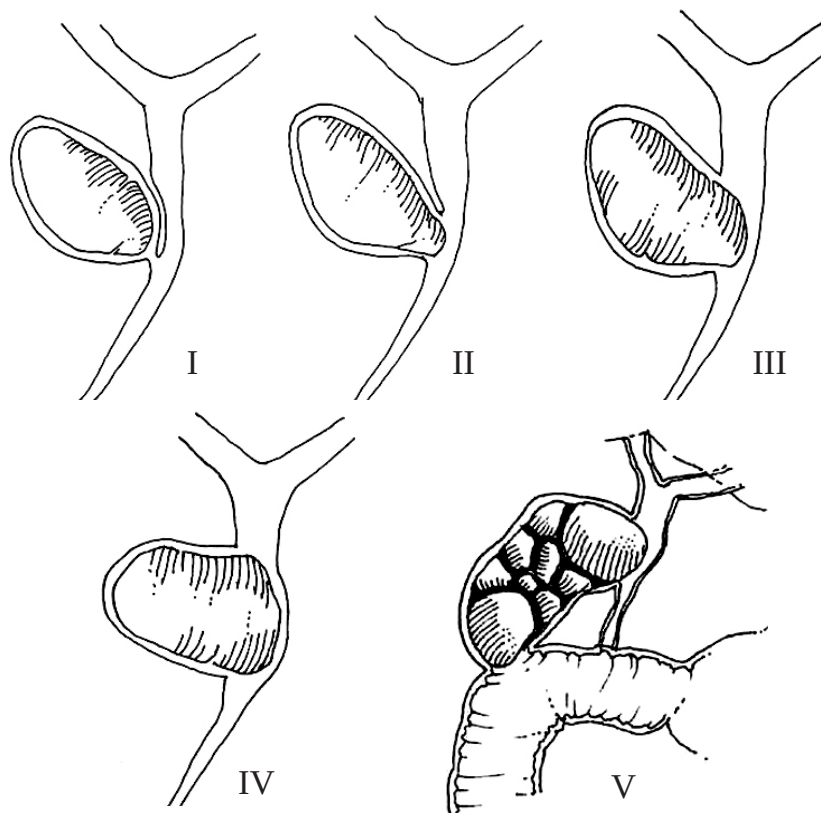

Рис. 1. Класифікація синдрому Міріззі за A. Csendes and M. Beltran. 
Розподіл пацієнтів за типом синдрому Міріззі представлено у таблиці 1.

Таблиця 1. Розподіл пацієнтів за локалізацією спонтанних внутрішніх біліарних нориць

\begin{tabular}{||l|c|c||}
\hline \multicolumn{1}{|c|}{ Тип нориці } & Кількість & $\%$ \\
\hline 1 & 81 & 41 \\
\hline 2 & 30 & 15 \\
\hline 3 & 14 & 7 \\
\hline 4 & 9 & 4,5 \\
\hline $\begin{array}{l}\text { Ха } \\
\text { Холецистодуоденальні } \\
\text { Холецистотовстокишкові } \\
\text { Комбіновані }\end{array}$ & 40 & 20 \\
\hline $\begin{array}{l}\text { 5б } \\
\text { Холецистогастральні }\end{array}$ & 3 & 1.5 \\
\hline Холедоходуоденальні & 22 & 11 \\
\hline Всього & 199 & 100 \\
\hline \hline
\end{tabular}

Також у дослідження ми включили окрему підгрупу пацієнтів, у яких діагностували холедоходуоденальні нориці, які не можна віднести до жодної з груп класифікації СМ за A. Csendes та M. Beltran. Ïх почали активно виявляти із збільшенням кількості ЕРПХГ і покращенням візуалізації під час ендоскопії. Таких хворих було 22 (11\%).

Результати досліджень та їх обговорення. Усім 199 хворим виконали холецистектомію 3 ліквідацією нориці і відновленням жовчовідтоку у просвіт травної трубки. У трьох пацієнтів операційні втручання розпочинали лапароскопічно, але у зв'язку з високим ризиком пошкодження позапечінкових жовчних проток здійснили конверсію. Пацієнтам із СМ 1 типу виконували холецистектомію із зашиванням широкої і короткої міхурової протоки. Ми спостерігали два варіанти анатомічних змін міхурової протоки у пацієнтів із СМ 1 типу:

А) Довга міхурова протока йде паралельно до ЗЖП і впадає в неї нижче звичайного, інколи - peтродуоденально;

Б) Міхурова протока скорочена внаслідок склерозування аж до її повної відсутності, при цьому ЖМ сполучається із холедохом через тонкий до 1-2 мм в діаметрі отвір, який не можна вважати норицею.

А-тип змін діагностували у 25 (30,27 \%) пацієнтів, Б-тип - у 56 (69,73 \%). При А-типі виконували стандартну холецистектомію “від шийки” після попередньої широкої дисекції гепатодуоденальної зв’язки для чіткої ідентифікації міхурової прото- ки і ЗЖП. При Б-типі ідентифікація міхурової протоки не була можливою, у такому разі виконували холецистектомію “від дна”. Тільки у 2 з 53 пацієнтів після цього були у змозі ідентифікувати склеротизовану міхурову протоку після тракції за відокремлений від печінки міхур. У інших пацієнтів міхур пересікали близько до ЗЖП і паралельно ӥй і зшивали передню і задню стінку залишеної кукси вузловими швами атравматикою прецизійно.

У 30 хворих із СМ 2 типу (рис. 2) виконали холецистектомію “від дна” з висіканням норицевого ходу і зашиванням дефекту у загальній жовчній протоці на Т-подібній трубці. Принциповим було проведення Т-подібної трубки через окремий розріз в супрадуоденальній частині ЗЖП, а не через норицевий отвір, що зменшувало навантаження на лінію швів ЗЖП. У 14 хворих із СМ 3 типу варіантом вибору була холецистектомія 3 пластикою ЗЖП залишками стінки жовчного міхура і зовнішнім дренуванням Т-подібною трубкою. У 9 хворих із синдромом Міріззі 4 типу виконали холецистектомію “від дна” із повним пересіканням ЗЖП. Відновлення пасажу жовчі досягли накладанням гепатикоєюноанастомозу між проксимальною куксою ЗЖП і петлею тонкої кишки, ізольованою за Ру. Ізольовану петлю створювали довгою - 80-90 см. Анастомоз накладали прецизійно атравматикою, що розсмоктується. Зовнішні або внутрішні дренажі не застосовували. Потовщення стінок і розширення проксимальної частини холедоха внаслідок хронічного запалення i склерозування тканин навколо фістули полегшувало створення анастомозу.

У 10 пацієнтів із холецисто-дуоденальними норицями (рис. 3) дефект передньої стінки дванадцятипалої кишки (ДПК) був розташований близько до пілоруса і мав розміри до 1 см, у зв'язку з чим для ліквідації дефекту виконували пілоропластику за Джадом. У 3 пацієнтів дефект стінки ДПК після висікання норицевого ходу був понад 1 см, мав неправильну форму і розташовувався на відстані від пілоруса. Оскільки виконати його висікання в такому випадку було б технічно складно, тому провели резекцію шлунка за Більрот II з гастроєюноанастомозом на ізольованій за Ру петлі тонкої кишки.

Схематичне зображення окремих видів спонтанних внутрішніх біліарних нориць та їх способів хірургічної корекції подано на рисунках 2-7.

У 6 пацієнтів із холецистодуоденальними норицями холецистектомія 3 висіканням норицевого ходу була виконана “від дна”. У жодного з пацієнтів цієї підгрупи ми не спостерігали обструктивної жовтяниці. 


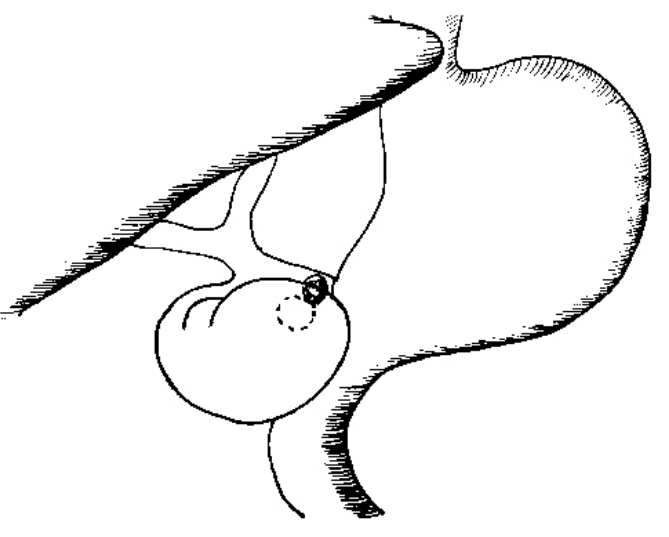

Рис. 2. Холецистохоледохеальна нориця. Холецистектомія + ушивання холедоха на дренажі Кера.

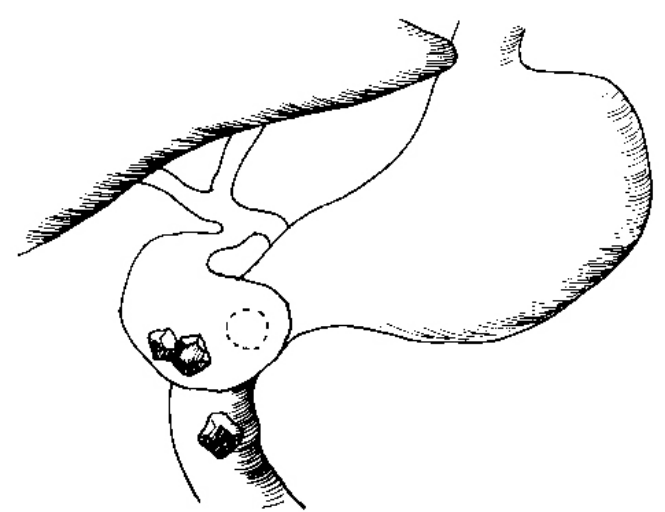

Рис. 3. Холецистодуоденальна нориця. Холецистектомія + ушивання дефекту і пілоропластика за Джадом або резекція шлунка за Більрот I.

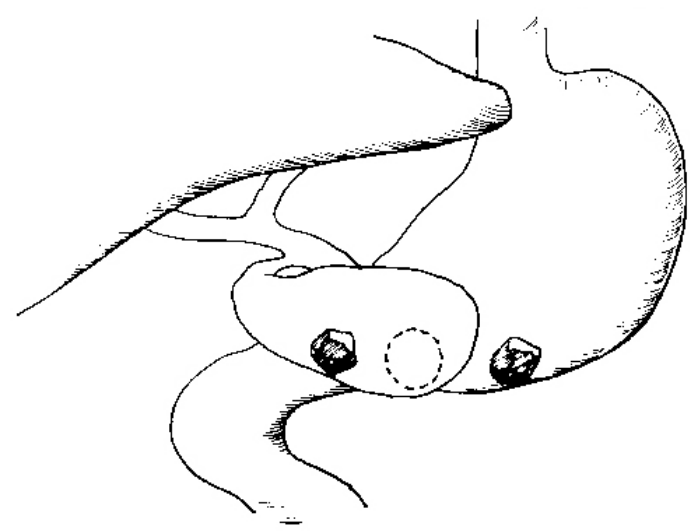

Рис. 4. Холецистогастральна нориця. Холецистектомія + висікання передньої стінки шлунка з поперечним ушиванням.

У 14 хворих із холецистогастральними норицями (див. рис. 4) виконали холецистектомію із висіканням норицевого ходу і закриттям дефекту

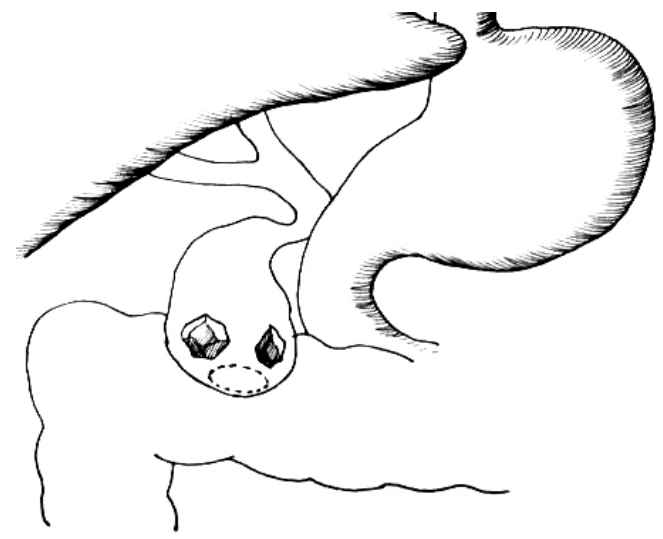

Рис. 5. Холецистотовстокишкова нориця. Холецистектомія + висікання норицевого отвору товстої кишки з поперечним ушиванням.

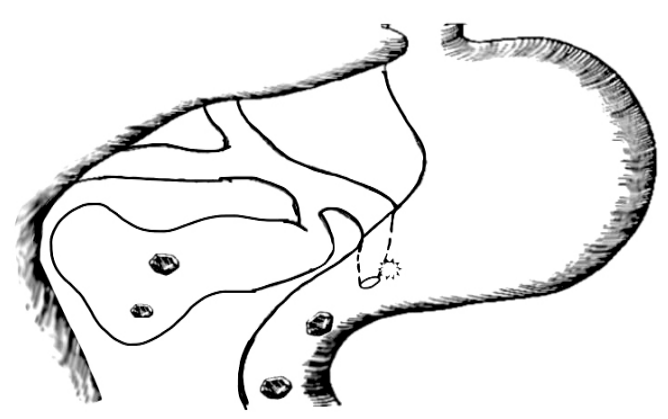

Рис. 6. Холедоходуоденальна нориця. Холецистектомія + ендоскопічна папіполофістулотомія або папілосфінктеротомія.

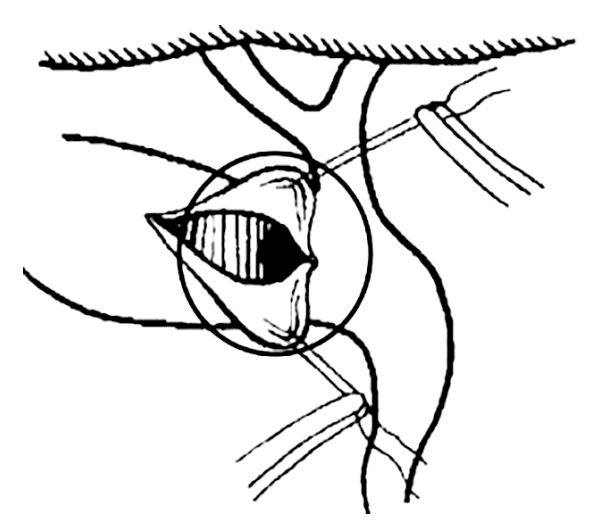

Рис. 7. Візуалізація єдиного отвору (виділений кільцем) у просвіті жовчного міхура.

стінки шлунка за типом пілоропластики за Джадом. У 3 хворих із холецистогастральними норицями спостерігали синдром Бувере - гостру киш- 
кову непрохідність внаслідок обструкції кишки конкрементом. Хірургічна тактика полягала у виконанні ретельної ревізії кишки та ентеротомії 3 метою видалення конкременту, зашиванні кишки в поперечному напрямку до її вісі. Також у жодного із цих хворих не було ознак жовчної обструкції.

У 10 пацієнтів із холецистотовстокишковими норицями (див. рис. 5) виконували холецистектомію із висіканням норицевого отвору печінкового кута товстої кишки. Дефект в стінці товстої кишки зашивали атравматикою у два ряди. У 3 хворих із комбінованими норицями, до яких приєднувались ЖМ, ЗЖП і товста кишка, виконали холецистектомію із пластикою ЗЖП залишками стінки ЖМ на Т-подібній трубці за Кером і зашивання дефекту стінки товстої кишки. У всіх пацієнтів була наявна клініка гострого холангіту і обструктивної жовтяниці. Три пацієнти із комбінованими норицями, утвореними ЖМ, ДПК та печінковим кутом товстої кишки, були проліковані шляхом холецистектомії від дна з висіканням нориці, зовнішнім дренуванням холедоха за Кером і зашиванням дефектів стінки ДПК та товстої кишки. У цих пацієнтів спостерігали гіпербілірубінемію і ознаки гострого холангіту, проте при ревізії в гепатикохоледоху конкрементів не виявлено, ймовірно, гіпербілірубінемія підтримувалась за рахунок гострого холангіту.

Серед пацієнтів з холедоходуоденальними норицями (див. рис. 6), за даними фібродуоденоскопії, ми виділяли два їх види залежно від місця розташування. Перший - коли норицевий отвір був розташований до межі перехідної складки великого соска дванадцятипалої кишки, другий - норицевий отвір розташований вище перехідної складки. У окремій підгрупі пацієнтів із холедоходуоденальними норицями 1 типу встановлено у 19 хворих і 2 - у 3. Дев'ятнадцяти хворим виконано ендоскопічну папілофістулотомію з метою надійного дренування ЗЖП, евакуції конкрементів з неї і ліквідації внутрішнього отвору нориці. При розташуванні норицевого ходу вище перехідної складки у трьох хворих виконана тільки папілосфінктеротомія з метою ліквідації сліпої кишені термінального холедоха від нориці до ампули соска.

Синдром Міріззі може бути зумовлений запальним процесом вторинним до ерозії, спричиненої вклиненням жовчних каменів в лійці жовчного міхура або сумці Гартмана і міхурової протоки [1, 10]. Запальний процес спричиняє утворення спайок, шляхом об'єднання стінок запальної набряклої тканини, що в кінцевому результаті стануть фіброзними до сусідніх структур; найчастіше це загальна жовчна протока, дванадцятипала кишка і товста кишки [9]. Прилеглість до жовчних про- ток сприяє зовнішньому стисненню останньої, що призводить до обструктивної жовтяниці [2, 10]. Вплив конкрементів разом із запальною реакцією зумовлює зовнішню обструкцію жовчної протоки, і в кінцевому результаті слизова оболонка буде піддаватись ерозії з утворенням холецистохоледохеальної або холецистопечінкової нориць, які становлять різний ступінь зв'язку між жовчними протоками і жовчним міхуром [1 -6].

Операції, застосовані до пацієнтів із 2, 3 і 4 типами СМ, вище описані ретроспективно. Проте ми можемо стверджувати, що обрати певний тип операції тільки після інтраопераційної ревізії зазвичай не можливо внаслідок складності визначення частини околу ЗЖП, залученого у фістулу. Ми запропонували послідовність операційних прийомів, яка робить таке визначення можливим. Спочатку відокремлювали жовчний міхур від печінки за способом “від дна”. Після цього розсікали передню стінку зморщеного жовчного міхура у напрямку до ЗЖП перпендикулярно її вісі. Краї розрізу розгортали і візуалізували міхуровий отвір холецистохоледохеальної нориці. Якщо візуалізувався один отвір, то його можна було зашити атравматикою а рештки жовчного міхура відсікти навколо зашитого місця практично без ризику пошкодження ЗЖП (див. рис. 7).

Якщо ж замість одного отвору візуалізували два, то робили висновок про поширення норицевого ходу на понад 2/3 околу ЗЖП (рис. 8).

У такій ситуації оцінювали стан решток ЖМ: якщо їх було достатньо для пластики, то робили бічну пластику ЗЖП прецизійно атравматикою на Т-подібній трубці. При недостатньому об’ємі

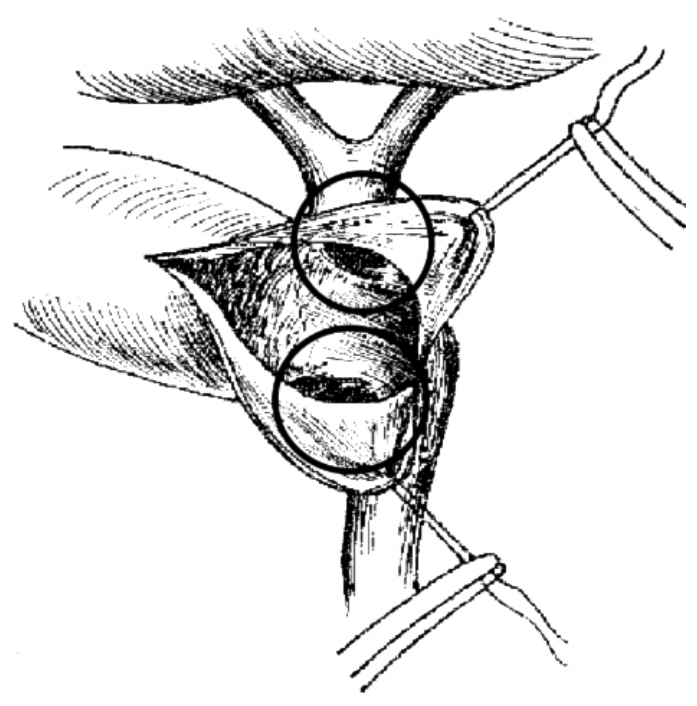

Рис. 8. Візуалізація двох отворів (виділені кільцями) у просвіті жовчного міхура. 
стінок ЖМ норицю висікали повністю із пересіканням холедоха і накладали гепатикоєюноанастомоз. Під час усіх операцій здійснювали ревізію гепатикохоледоха зондами, ложками і щипцями. За необхідності виконували холедохолітоекстракцію. У пацієнтів, яким до операції виконували ендоскопічну папілосфінктеротомію (ЕПСТ), під час ревізії гепатикохоледоха конкрементів не виявляли, що свідчило про їх спонтанне відходження після ЕПСТ. Ускладнень після ендоскопічних операцій не було. У всіх пацієнтів окремої підгрупи у різні строки після ендоскопічних втручань виконали холецистектомію з ревізією ЗЖП. Необхідність в холедохолітоекстракції виникла тільки у 4 (21 \%) пацієнтів, зовнішнє дренування ЗЖП не застосовували в жодному разі.

Серед усіх 199 пацієнтів померли 4. Загальна летальність склала 2 \%.

\section{СПИСОК ЛІТЕРАТУРИ}

1. Syplyviy V. Surgical management of patients with Mirizzi syndrome / V. Syplyviy, D. Ievtushenko, G. Petrenko, A. Ievtushenko // HPB. - 2016. - No. 18. - P. 674-675.

2. Dutka Y. The special features of surgical treatment of patients with the Mirizzi syndrome / Y. Dutka, S. Chooklin // HPB. 2016. - No. 18. - P. 820

3. Біліодигестивні нориці і непрохідність кишківника, спричинена жовчевими каменями, в практиці ургентної ендоскопії: огляд літератури і власний досвід / М. Є. Артюшенко, I. М. Тумак, Л. М. Когут [та ін.] // Український журнал малоінвазивної та ендоскопічної хірургії. - 2012. - Vol. 16, № 2. - C. 20-22.

4. Oter V. Surgical outcomes of mirizzi syndrome: a single institution's experience of 34 cases / V. Oter // Laparoscopic Endoscopic Surgical Science. - 2017. - Vol. 24, No. 3. - P. 94-98. 5. Zaporozhchenko B. S. Modern diagnostic methods and approaches to the surgical treatment of Mirizzi syndrome / B. S. Zaporozhchenko, D. A. Bondarets, I. E. Borodaev [et al.] //

\section{REFERENCES}

1. Syplyviy, V., Ievtushenko, D., Petrenko, G., \& Ievtushenko, A. (2016). Surgical management of patients with Mirizzi syndrome. HPB, 18, e674-e675. doi: 10.1016/j.hpb.2016.01.033

2. Dutka, Y., \& Chooklin, S. (2016). The special features of surgical treatment of patients with the Mirizzi syndrome. $H P B$, 18, e820. doi: 10.1016/j.hpb.2016.01.389

3. Artiushenko, M., Tumak, I., \& Kohut, L. (2012). Biliodyhestyvni norytsi i neprokhidnist kyshkivnyka, sprychynena zhovchevymy kameniami, v praktytsi urhentnoi endoskopii: ohliad literatury i vlasnyi dosvid [Bio-digestive figures and intestinal intestination caused by gallstones, in practice of urgent endoscopy: literature review and own experience]. Ukrainskyi zhurnal maloinvazyvnoi ta endoskopichnoi khirurhii - Ukrainian Journal of Minimally Invasive and Endoscopic Surgery, 16 (2), 20 -22 [in Ukrainian].

4. Oter, V. (2017). Surgical outcomes of mirizzi syndrome: a single institution's experience of 34 cases. Laparoscopic Endoscopic Surgical Science. doi: 10.14744/less.2017.79664

5. Zaporozhchenko, B., Bondarets, D., Borodaev, I., Kachanov, V., Muravyov, P., Zubkov, O., \& Gorbunov, A. (2018).
Висновки. Метою операції при спонтанних внутрішніх біліарних норицях $є$ видалення жовчного міхура, забезпечення відтоку жовчі у просвіт травної трубки і пасажу хімусу по ній. При приєднанні у процес позапечінкових жовчних проток необхідна холедохолітоекстракція, їх пластична реконструкція із тимчасовим зовнішнім дренуванням або анастомозування із петлею тонкої кишки. При наявності нориці в порожнистому органі виконується її висікання з ушиванням отвору, в окремих випадках резекційні способи ліквідації нориць.

Пацієнтам із холедоходуоденальними норицями показана папілосфінктерофістулотомія при локалізації внутрішнього отвору фістули в межах перехідної складки великого дуоденального сосочка, а за межами перехідної складки - папілосфінктеротомія.

Ukrainian Journal of Surgery. - 2017. - Vol. 35, No. 4. - P. 33-37 6. Current trends in the management of Mirizzi syndrome. Medicine / H. Chen, E. Siwo, M. Khu, Y. Tian // Medicine. 2018. - Vol. 97, No. 4.

7. Beltrán M. A. Mirizzi syndrome: history, current knowledge and proposal of a simplified classification / M. A. Beltrán // World Journal of Gastroenterology: WJG. - 2012. - Vol. 18, No. 344. P. 4639-4650

8. Rayapudi K. Mirizzi syndrome with endoscopic ultrasound image / K. Rayapudi, P. Gholami, M. Olyaee // Case Reports in Gastroenterology. - 2013. - Vol. 7, No. 2. - P. 202-207.

9. Updates in Mirizzi syndrome / A. I. Valderrama-Treviño, J. J. Granados-Romero, M. Espejel-Deloiza [et al]. // Hepatobiliary Surgery and Nutrition. - 2017. - Vol. 6, No. 3. - P. 170-178

10. Lee K. Mirizzi syndrome: a new approach to an old problem / K. Lee // Hepatobiliary Surgery and Nutrition. - 2018. - Vol. 7, No. 1. - P. 56-57

Modern diagnostic methods and approaches to the surgical treatment of Mirizzi syndrome. Ukrainian Journal of Surgery, 35 (4), 33-37. doi: 10.22141/1997-2938.4.35.2017.118890

6. Chen, H., Siwo, E., Khu, M., \& Tian, Y. (2018). Current trends in the management of Mirizzi syndrome. Medicine, 97 (4), e9691. doi: 10.1097/md.0000000000009691

7. Beltrán, M. (2012). Mirizzi syndrome: History, current knowledge and proposal of a simplified classification. World Journal of Gastroenterology, 18 (34), 4639. doi: 10.3748/wjg.v18.i34.4639 8. Rayapudi, K., Gholami, P., \& Olyaee, M. (2013). Mirizzi syndrome with endoscopic ultrasound image. Case Reports in Gastroenterology, 7 (2), 202-207. doi: 10.1159/000351170

9. Valderrama-Treviño, A., Granados-Romero, J., Espejel-Deloiza, M., Chernitzky-Camaño, J., Barrera Mera, B., \& Estrada-Mata, A. (2017). Updates in Mirizzi syndrome. Hepatobiliary Surgery and Nutrition, 6 (3), 170-178. doi: 10.21037/hbsn.2016.11.01

10. Lee, K. (2018). Mirizzi syndrome: a new approach to an old problem. Hepatobiliary Surgery and Nutrition, 7 (1), 56-57. doi: 10.21037/hbsn.2017.12.09

Отримано 05.03.2019 


\title{
V. I. RUSYN, K. E. RUMIANTSEV, F.M. PAVUK
}

Uzhhorod National University

\section{TREATMENT OF MIRIZZI SYNDROME}

The aim of the work: determination of the method of surgical treatment of spontaneous internal biliary fistulas (SIBF) in Mirizzi syndrome.

Materials and Methods. A retrospective analysis of results of the treatment of 8200 patients with cholelithiasis in regional Andrii Novak Hospital from 1997 to 2018. Among them, 199 patients were observed with SIBF. The frequency with which the SIBF occurred was $2.4 \%$.

Results and Discussion. Patients with MS type 1 underwent cholecystectomy with sewing of the wide and short bladder duct. In 30 patients with MS type 2, cholecystectomy was performed from the bottom with the incision of the fistula and the sewing of the defect in the common bile duct (CBD) on a T-tube. In 14 patients with MS type 3, the choice was cholecystectomy with plastic surgery with the remnants of the wall of the gallbladder and external drainage of the T-tube. 9 patients with Mirizzi syndrome type 4 underwent cholecystectomy "from the bottom" with a complete intersection of CBD. Nineteen patients with choledocho-duodenal fistulae type I were performed endoscopic papillofystulotomy for the purpose of reliable drainage of CBD, evacuation of concrements from it, and elimination of the intrathoracic fistula opening. The purpose of the operation in spontaneous internal biliary fistula is to remove the gallbladder, to ensure the flow of bile into the lumen of the digestive tube and the chyme passage on it. In the presence of a fistula in the digestive organ, its incision is performed with hole sewing, in some cases resection methods for the elimination of the fistula.

Key words: Mirizzi syndrome; mechanical jaundice; choledocholithiasis; spontaneous internal biliary fistula.

\author{
В. И. РУСИН, К. Е. РУМЯНЦЕВ, Ф. Н. ПАВУК
}

ГВУз “Ужгородский национальный университет”

\section{ЛЕЧЕНИЕ СИНДРОМА МИРИЗЗИ}

Цель работы: определение способа лечения спонтанных внутренних билиарных свищей (СВБС) при синдроме Мириззи (СМ). Материалы и методы. Проведен ретроспективный анализ результатов лечения 8200 пациентов с желчнокаменной болезнью в Закарпатской областной клинической больнице имени Андрея Новака (ЗОКБ) с 1997 по 2018 гг. Из общего количества в 199 пациентов наблюдали СВБС. Частота, с которой случались СВБС, составила 2,4%.

Результаты исследований и их обсуждение. Пациентам с СМ 1 типа выполняли холецистэктомию с зашиванием широкого и короткого пузырного протока. У 30 больных с СМ 2 типа выполнили холецистэктомию от дна с иссечением свищевого хода и зашивания дефекта в общем желчном протоке (ОЖП) на Т-образной трубке. У 14 больных с СМ 3 типа вариантом выбора была холецистэктомия с пластикой ОЖП остатками стенки желчного пузыря и наружным дренированием Т-образной трубкой. У 9 больных с синдромом Мириззи 4 типа выполнили холецистэктомию “от дна” с полным пересечением ОЖП. Девятнадцати больным с холедохо-дуоденальными свищами 1 типа выполнено эндоскопическую папилофистулотомию с целью надежного дренирования ОЖП, эвакуации конкрементов из нее и ликвидации внутреннего отверстия свища. Целью операции при спонтанных внутренних билиарных свищях является удаление желчного пузыря, обеспечение оттока желчи в просвет пищеварительной трубки и пассажа химуса по ней. При наличии свища в полом органе выполняется его иссечение с ушиванием отверстия, в отдельных случаях резекционные способы ликвидации свищей.

Ключевые слова: синдром Мириззи; механическая желтуха; холедохолитиаз; спонтанные внутренние билиарные свищи. 